\section{African Natives and Imperial Citizenship}

IN his presidential address on "Imperial Citizenship" to the sixth Imperial Social Hygiene Congress on July 7, Sir Basil Blackett made some extremely pertinent remarks on the need for recreating the spirit of obligation towards backward peoples formerly expressed in now obsolete phrases such as 'the white man's burden'. He added point to his remarks by drawing on his own experience of only a few weeks ago when visiting a native tribe in South Africa and contrasting the friendly attitude of the natives and their recognition of the fact that they were, with himself, full subjects of the King-Emperor, with what would have been his fate had he visited them only two generations ago. He went on to point out, however, that while the British forces of law and order in Africa are combatting witch-craft, cannibalism and superstition, and the African is becoming accustomed to a law-abiding life such as he never experienced before, our task to-day is changed. No longer should an attempt be made to thrust a western civilisation down the throats of native races. While trying to give them the best of our civilisation, we should help them to develop along their own lines without making them detribalised Africans or imitation Europeans. Sir Basil went on to point out that the world-wide distribution of the British Empire gives a peculiar value to an imperial conference such as the Social Hygiene Congress in relation to the study of world problems. On the other hand, he deplored the apparent disinclination of Britain to take the lead as she did in the nineteenth century. Such a lethargy is apparent throughout the whole of Africa to-day. By doing her duty to the Empire, he maintains, Britain would at the same time give a lead to the whole world.

\section{Centenary of William Wilberforce}

ON July 23-30, Hull will commemorate the centenary of the death of William Wilberforce and the abolition of slavery within British possessions. William Wilberforce, Hull's most distinguished citizen, was born in 1759 in the house which is now the Wilberforce Museum, and represented Yorkshire in Parliament from 1784 until 1812. He died in 1833 a few days after the Act for the abolition of slavery had been passed. The commemoration will open on July 23 with a civic commemoration service at Holy Trinity Church, to which the Lord Mayor and Corporation, members of the Wilberforce family and representatives of the public bodies of Hull will go in procession. On July 24, exhibitions of autograph letters and books relating to Wilberforce at the Public Library and the Wilberforce centenary exhibition at the Mortimer Galleries will be declared open and will remain open throughout the week. The exhibition at the Mortimer Galleries will include a number of slave relics and paintings. In the evening a civic reception of the Wilberforce family will be held in the Guildhall. Other features of the commemoration will be "William Wilberforce", a radio chronicle play by Edwin Lewis and Albert
Dunning, performed by the Hull Playgoers Society ; a ceremonial civic tribute at the Wilberforce Monument, City Square, and an address by Prof. R. Coupland, professor of Colonial history at the University of Oxford, on "The Life and Work of Wilberforce", to be delivered at a luncheon at the Guildhall on July 25. The arrangements have been in the hands of an executive committee of which the Lord Mayor, Alderman J. Malcolm Dossor, is chairman, and a programme has been prepared by $\mathrm{Mr}$. T. Sheppard, curator of museums.

\section{Coloration in Lizards}

CAPT. INGRAM has just returned from Round Island, Mauritius, bringing with him a collection of lizards made there. These he has presented to the Zoological Society of London. It is perhaps not surprising to find that they are all new to the Gardens, for very little collecting has ever been done on this island. The most interesting species included in this gift is a small and very beautiful jewelled gecko, having the upper surface of a greenish hue, and the lower white. But this background is enlivened by some strikingly vivid colouring. The head has a ground-colour of peacock-blue with scarlet markings and cross-shaped bars on the forehead, while stripes and spots ornament the back. This suggests a 'warning' coloration. Some years ago its very opposite was to be seen in the Reptile House. This was the lichen-bark gecko, Uroplates fimbriatus, wherein the markings on the body afforded a most convincing illustration of 'protective coloration'. Even when seen in a glass case, from a distance of a few inches it could scarcely be distinguished from the bark on which it was resting, the patches of lichen-grey on a black background completely breaking up the solid appearance of the body. The illusion was made the more complete by a large outstanding pleat of skin running down each side of the body and tail, which caused an insensible transition between the animal and its resting place, the fold of skin being closely applied to the bark.

IT is not only on account of their coloration, which changes almost as readily as that of the chamæleon, that the geckos claim our interest, for all the species, save those which have become adjusted to a desert life, have peculiar expansions on the under-surface of the toes whereby they can climb, even up panes of glass, or along the ceiling of a room, with as much facility as a fly. These pads are formed of compressible, vertical folds which, on pressure, form vacua furnishing secure adhesion even to a body more than five inches long. These creatures, like many other lizards, also have the tail so modified that when seized by this organ it at once breaks off, thereby enabling the intended captive to escape; later, it grows a new tail.

\section{The Buckston Browne Research Farm}

ON July 12 the Buckston Browne Research Farm, at Downe, Kent, was formally opened by the president of the Royal College of Surgeons of England, Sir 
Holburt Waring. The Farm is intended to provide young surgeons with opportunities of extending our knowledge of the biological processes which underlie the art of surgery. Already a series of experimental inquiries has been set on foot to determine how far surgical methods can be employed for the cure or relief of the graver forms of pulmonary tuberculosis. In his opening address, Sir Holburt Waring outlined some of the clinical conditions which require experimental elucidation. He cited particularly the grave mortality which still attends intestinal obstruction and the need for further study of the condition known as surgical shock. The Research Farm, which is $16 \frac{1}{2}$ miles from Charing Cross, is the gift of Sir Buckston Browne, a distinguished London surgeon and a fellow of the Royal College of Surgeons. Rather more than two years ago he gave $£ 100,000$ to his College in order that it might be able to add a research station in the country to the experimental laboratories already established in connexion with the Hunterian Museum in Lincoln's Inn Fields.

As is well known, John Hunter, the celebrated surgeon of the eighteenth century, carried on his experimental work at his farm at Earl's Court. Sir Buckston Browne wished to present a modern representation of Hunter's Earl's Court Farm to his College and chose a site in the parish of Downe, Kent, adjacent to the home of Charles Darwin. It will be remembered that in 1928 Sir Buckston purchased Darwin's home, Down House, and after restoring and endowing it, presented it to the British Association. The Research Farm is built on land which adjoins the gardens and grounds of Down House. Sir Buckston Browne has thus established side by side in Darwin's parish two bodies which encourage research, namely, the British Association for the Advancement of Science and the Royal College of Surgeons of England. Dr. O. J. R. Howarth is resident officer at Down House, while Sir Arthur Keith is in charge of the Buckston Browne Research Farm.

\section{Cancer Research}

THE tenth annual report of the British Empire Cancer Campaign notices a considerable variety of investigations into the nature, cause and treatment of cancer, which are being carried on under its auspices in different parts of the world. Three of the results obtained especially are of general interest. At the Cancer Hospital, Prof. E. L. Kennaway, Dr. J. W. Cook and their colleagues have now isolated the substance (or one of the substances) to which tar owes its peculiar carcinogenic properties: it proves to be 1:2-benzpyrene. No evidence was obtained of the presence of the dibenzanthracene which the same workers have synthesised and shown to be nearly equally active, and, along with Prof. E. C. Dodds, to have a remarkable influence on the sexual cycle in animals. It remains to be discovered whether these or similar substances are ever produced in the body and so form the intermediaries whereby chronic irritation and injury give rise to tumours. At the Middlesex Hospital, Prof. J.
McIntosh has made the notable discovery that some at least of the connective tissue tumours produced in fowls by tar can be transmitted by a filtrable agent. The experimental growths thus come into line with the natural bird tumours which have been so much studied. No clear mammalian tumour has yet been shown to be certainly filtrable.

\section{A Virus from Influenza Patients}

The causation of epidemic influenza has proved a perplexing problem for the bacteriologist. Of the bacterial organisms associated with the disease, Pfeiffer's influenza bacillus, the most frequent, and others do not appear to be capable of reproducing the cardinal features of the disease, but only some of the secondary symptoms. Another difficulty encountered is the insusceptibility of most animals to human influenza, the so-called influenzas of animals being distinct from the human. Latterly, attempts have been made to detect a virus in the disease, hitherto with little or no success, but in a recent communication, Smith, Andrewes and Laidlaw describe results obtained with ferrets (Lancet, July 8, p. 66). A febrile disease is produced in ferrets by the intranasal instillation of filtrates of throat washings obtained from influenza patients, which is transmissible serially in ferrets either by contact or by intranasal instillation of virus material from infected ferrets. Filtration was conducted through 'Gradocol' membranes so that the filtrate is bacteriafree. Throat-washings from healthy persons and influenza convalescents caused no illness in ferrets. The disease in ferrets has some likeness to human influenza, with nasal and pulmonary catarrh and occasionally a relapse. The blood-serum of a ferret that has recovered, and also that of recovered human cases, neutralises the virus. The virus of swine influenza, described by Shope, has a close antigenic relationship with the influenza virus, and induces a disease in ferrets very like that produced with the influenza virus. A prima facie case has indirectly been made out for an attempt to transfer the ferret disease back again to man, and a technique has been discovered which can be exploited fruitfully when the next human epidemic occurs.

\section{Massive Radium Unit for Treatment}

Ix may be recalled that the Radium Committee decided last year to withdraw and dismantle the four-gram radium 'bomb' used for massive radiation at Westminster Hospital. Some doubt was expressed at the time of the wisdom of this step, but a conference called by the Royal Colleges of Physicians and Surgeons endorsed the policy, at the same time appointing a committee of experts to reconsider the case for mass radiation. After visits to radium treatment centres abroad, the committee reported that it is desirable that a radium unit of not less than five grams should be established, so that research can be undertaken on the value of what is best termed 'beam' therapy. For this purpose, a representative governing body with Sir Frederick Gowland Hopkins as chairman was constituted. After negotia- 